\begin{tabular}{c|c|c}
\hline $\begin{array}{c}\text { Jurnal Penelitian Keperawatan } \\
\text { Medik }\end{array}$ & Vol. 2 No. 1 & Edition: May - October 2019 \\
\hline & $\frac{\text { http://ejournal.delihusada.ac.id/index.php/JPKM }}{2019}$ & Revised: 28 October 2019 \\
\hline Received: 16 October 2019 & & \\
\hline
\end{tabular}

\title{
COGNITIVE BEHAVIOUR THERAPY PADA SKIZOFRENIA
}

\author{
Ira Aini Dania \\ Universitas Islam Sumatera Utara \\ Email: iraaini27@gmail.com
}

\begin{abstract}
Cognitive Behaviour Therapy (CBT) in the first schizophrenia was developed to provide additional treatment for residual symptoms arising and also used in patients experiencing anxiety and depression. Rapid progress will gain from the CBT session when trust has built-in several meeting sessions through increasing mutual understanding and doing reality tests as in CBT, need to develop. The stages do run slowly following the cognitive deficits and ongoing symptoms such as hallucinations or sedentary. This article discusses the history and development of cognitive behavior therapy, depictions, procedures, and techniques of CBT and its processes in the treatment of schizophrenia.
\end{abstract}

Keyword: Cognitive behavior therapy, schizophrenia, psychological

\section{PENDAHULUAN}

Skizofrenia merupakan gangguan mental serius yang terdapat di populasi sekitar $1 \%$ tanpa memandang budaya, status sosial, dan suku. Gangguan ini bervariasi keparahannya dan memiliki simtom yang bervariasi. Hampir setiap tahunnya satu dari seribu populasi berpeluang mengidap penyakit skizofrenia (Jones et.al., 2008).

Efektifitas penggunaan antipsikotik didalam pengobatan psikosis akut dalam upaya mencegah terjadinya relaps masih banyak menimbulkan efek samping pada penderita skizofrenia yang tetap mengalami simtom psikotik lanjut. Sekitar 5-25\% penderita skizofrenia yang menjalani pengobatan rutin dengan obat antipsikotik tetap mengalami simtom psikosis dan selalu mengalami masalah dengan efek samping yang ditimbulkan dari penggunaan antipsikotik (Jones, et.al., 2008; Gould, et.al., 2004).

Penelitian yang dilakukan oleh beberapa penulis menyebutkan bahwa penggunaan Cognitive Behaviour Therapy (CBT) dalam pengobatan skizofrenia dapat mengubah distorsi pemikiran yang telah terjadi dan membawa penderita skizofrenia melihat segala sesuatu lebih rasional dan realistik. CBT yang dilakukan secara perlahan tetapi pasti membantu pasien untuk melihat alternatif cara berpikir tentang sesuatu hal (Kingdon, et.al., 2004).
Beberapa pembuktian tentang efikasi CBT pada pasien skizofrenia yang memiliki simtom persisten menunjukkan kemajuan yang baik yang telah dilakukan melalui berbagai studi kasus dan beberapa penelitian dengan menggunakan metode pengambilan sampel acak sehingga uji klinis yang melibatkan pasien-pasien skizofrenia baik pada fase akut maupun kronis, serta melalui meta-analisis dan sistematic review (Hansen, et.al., 2006).

CBT pada skizofrenia pertama kali dikembangkan sebagai alternatif pengobatan tambahan bagi simtom residual yang timbul dan juga digunakan pada penderita yang mengalami kecemasan dan depresi. Pada tahun 1950an Aaron Beck telah mengobati penderita psikotik dengan menggunakan pendekatan kognitif (Hansen, et.al., 2006). Beck menggali secara lebih detil mengenai kejadian hidup yang dialami oleh pasien hingga mengalami suatu waham, pasien diminta untuk untuk mendeskripsikan secara jelas gambaran wahamnya tersebut dan mencatat apa tindakan yang dilakukan dan memperhatikan ekspresi wajah, perilaku secara umum, dan cara bersikap (Turkington, et.al., 2006b), akan tetapi tidak ada penelitian lanjutan selama beberapa saat, baru ketika tahun 1990an setelah dilakukan penggunaan terapi kognitif yang hanya digunakan untuk mengatasi kecemasan dan depresi, penelitian- 


\begin{tabular}{c|c|c}
\hline $\begin{array}{c}\text { Jurnal Penelitian Keperawatan } \\
\text { Medik }\end{array}$ & Vol. 2 No. 1 & Edition: May - October 2019 \\
\hline & $\frac{\text { http://ejournal.delihusada.ac.id/index.php/JPKM }}{\text { Revised: 28 October 2019 }}$ & Accepted: 31 October 2019 \\
\hline Received: 16 October 2019 & & \\
\hline
\end{tabular}

penelitian terhadap penderita psikotik dimulai kembali (Hansen, et.al., 2006).

Telah lebih dari lima puluh tahun CBT menjadi lebih efektif didalam intervensi psikososial. Pendekatan terapi perilaku pertama kali berkembang pada tahun 1950an ketika beberapa penelitian yang dilakukan atas dasar prinsip perilaku dan diterapkan kembali setelah mengalami modifikasi dari perilaku manusia yang maladaptif (Stevens, et.al., 2004).

Istilah CBT dalam penggunaannya berhubungan dengan terapi perilaku dan terapi kognitif, maupun merupakan penggabungan antara keduanya (Turkington, et.al., 1998). CBT merupakan rangkaian terapi yang didasarkan atas konsep dan prinsip yang diperoleh dari model psikologis yang mempelajari mengenai emosi dan perilaku manusia, sementara CBT tradisional lebih berorientasi terhadap perilaku saja (Turkington, et.al., 1998).

CBT merupakan pendekatan psikologis yang dilakukan berdasarkan atas prinsip-prinsip keilmuan yang telah diuji oleh penelitian-penelitian dan menunjukkan efektivitasnya didalam mengatasi suatu masalah. Di antara ahli terapi dan pasien diajak untuk dapat bekerjasama, hingga saat telah terbentuk hubungan terapi antar keduanya baru mulai diidentifikasi. Mencoba mengerti masalah yang dihadapi dengan melibatkan antara pikiran, perasaan dan perilaku merupakan intinya. Pendekatan yang dilakukan biasanya difokuskan pada aspek kesulitan yang timbul, dimana ahli terapi dan pasien bersama-sama mulai mengembangkan dan mendiskusikan bersama masalah yang dihadapi oleh pasien (Turkington, et.al., 1998).

Haddock dan kawan-kawan mencatat bahwa beberapa komunitas perawat psikiatri merupakan posisi kunci dalam intervensi CBT terhadap pasien skizofrenia didalam lingkungannya. Pemberian CBT yang ringkas dan sederhana yang dilakukan oleh perawat psikiatri adalah dengan memasukkan psikoedukasi dan intervensi keluarga. Para perawat psikiatri tersebut adalah mereka yang telah dilatih dan di supervisi oleh ahli terapi CBT selama lebih dari sepuluh hari. Secara keseluruhan simtom depresi, tilikan, secara signifikan menunjukkan perbaikan pada kelompok yang diobati dengan kombinasi CBT dan farmakologi dibandingkan dengan kelompok yang mendapat pengobatan dengan pelayanan standar. Menariknya penelitian ini adalah tidak memperbaiki simtom positif maupun simtom negatif. Hal ini mungkin berhubungan dengan kecepatan dan ketepatan pada saat melakukan CBT (Turkington, et.al., 2006a).

Kemajuan yang cepat akan didapat dari sesi CBT, ketika kepercayaan telah dibangun dalam beberapa sesi pertemuan melalui peningkatan rasa saling pengertian dan melakukan tes realita seperti didalam CBT perlu dikembangkan. Suatu hubungan saling mempercayai harus dibangun terlebih dulu sehingga terjadi suatu kolaborasi yang nyata agar dapat berjalan baik. Tahapannya memang berjalan perlahan mengikuti defisit kognitif yang terjadi dan simtom-simtom yang sedang berlangsung seperti adanya halusinasi atau waham yang menetap. Hanya ada satu target masalah yang dihubungkan dengan cara memberikan latihan pekerjaan rumah setiap sesi pertemuan. Semua pasien dalam hal ini kecuali mereka yang terlihat sangat paranoid biasanya tidak menganggap CBT sebagai suatu masalah bila kita menggunakan alat bantu perekam pembicaraan. Pada setiap sesi pembicaraan dimana penggunaan kaset rekaman ini diharapkan dapat didengar kembali dirumah yang digambarkan melalui kaset rekaman (Turkington, et.al., 2008).

Ahli terapi harus dapat selalu menjaga dan memelihara pemikiran yang terbuka saat mereka memulai sesi pertemuan pertama dan mulai mempersiapkan secara terbuka kepercayaan mereka sendiri dalam suatu hubungan yang luas dari berbagai subjek (Turkington, et.al., 2008).

Hampir beberapa dekade skizofrenia tidak berespons terhadap individual psikoterapi, dianggap hal tersebut hanyalah menghabis-habiskan waktu untuk berbicara dengan pasien skizofrenia mengenai masalah waham dan halusinasi, selain itu psikoterapi individu membutuhkan tes yang terus- 


\begin{tabular}{|c|c|c|}
\hline $\begin{array}{c}\text { Jurnal Penelitian Keperawatan } \\
\text { Medik }\end{array}$ & Vol. 2 No. 1 & Edition: May - October 2019 \\
\hline & http://ejournal.delihusada.ac.id/index.php/JPKM & \\
\hline Received: 16 October 2019 & Revised: 28 October 2019 & Accepted: 31 October 2019 \\
\hline
\end{tabular}

menerus, maka CBT pada skizofrenia mengharuskan dilakukan penelitian secara acak dan uji coba untuk membuktikan bahwa CBT skizofrenia memang dibutuhkan, seperti penelitian yang dilakukan oleh Drury dan kawan-kawan 1996 yang melakukan percobaan terhadap kelompok CBT dan kelompok recreational activitiesand support, yang dilakukan lebih dari 12 sesi selama enam bulan selama fase akut, ternyata didalam penelitian ini simtom positif memberikan respons yang baik dan lebih cepat pada kelompok yang diberikan CBT tetapi ini tidak bertahan lama hanya sekitar lima tahun saja. Begitu juga penelitian yang dilakukan oleh Bach dan Hayes, baru penelitian yang dilakukan oleh Kuipers dan kawan-kawan menunjukkan bahwa CBT secara umum mengurangi simtom psikiatri dan memberikan respons yang lebih baik hingga 50\% (Turkington, et.al., 2006b).

Beberapa keterbatasan yang terjadi selama penelitian awal tentang CBT ada beberapa faktor antara lain: Jumlah pasien yang terlalu sedikit, tidak adanya kelompok pembanding yang menggunakan psikoterapi, kurangnya penafsiran dari peneliti, kurangnya ketaatan menggunakan skala pengukuran pada setiap sesi pertemuan (Turkington, et.al., 2006b). Meta-analisis yang dilakukan oleh Gould (2004) menunjukkan CBT secara signifikan memperbaiki simtom positif dan simtom negatif, bahkan hingga saat ini belum ada pembuktian yang berhubungan dengan percobaan bunuh diri yang berkembang selama periode CBT (Hansen, et.al., 2006).

\section{GAMBARAN CBT}

Tujuan utama dari penggunaan CBT adalah suatu cara untuk dapat membuat seseorang menjadi mudah masuk dalam lingkungannya termasuk pengalaman psikotik yang berpengaruh terhadap afek dan perilaku (Turkington, et.al., 2006a).

Pendekatan CBT pada skizofrenia adalah suatu hal yang penting yang menghubungkan pikiran dan perasaan terhadap simtom-simtom yang ada saat ini dan kemudian mengevaluasi kembali pemikiran-pemikiran tersebut dalam hubungannya dengan realita (Turkington, et.al., 2006a).

Unsur terpenting didalam CBT pada skizofrenia adalah bentuk kepercayaan terhadap gabungan terapi yang memfokuskan pada adanya suatu ikatan antara pasien psikotik dengan pemeriksa yang harus selalu terjaga dan dipelihara disetiap sesi pertemuannya dan diperlukan kehatihatian dan pertimbangan pada saat melakukan eksplorasi sebelum melanjutkan pada penjelasan berikutnya. Jadwal setiap sesi pertemuan dikembangkan dan perlu diberi perhatian terhadap adanya halusinasi dan waham yang sering menonjol. Pasien kadang sering menginginkan mengerti segala sesuatu dengan lebih baik, merasa lebih terkontrol, atau dapat menggunakan coping mechanism. Tindakan berkonfrontasi dan menantang sebaiknya dihindari untuk tetap menjaga dalam bingkai fokus pertanyaan dan pembuktian bersama tanpa harus ada penghukuman (Turkington, et.al., 2006a).

Latihan mengerjakan pekerjaan rumah dengan menggunakan alat perlengkapan lain diperlukan untuk dukungan penjelasan tentang penyebab terjadinya simtom psikotik, dimana pasien psikotik biasanya menyerah dengan tidak dapat menjelaskan suatu hal. Sebagai contoh jika pasien mempercayai bahwa bisikan yang didengarnya berasal dari bisikan setan maka pasien mungkin merasa lebih tenang ketika dia harus mempertimbangkan sesuatu yang kurang menakutkan (Turkington, et.al., 2006a).

CBT pada skizofrenia juga harus dibedakan dari model CBT tradisional yang pendekatannya lebih ditekankan pada menormalkan pengalaman psikotik. Dimana pemikiran rasional tentang normal sangat membantu didalam decatastrophic pengalaman psikotik (Hansen, et.al., 2006; Turkington, et.al., 2006a).

Pada saat mengamati waham yang terbaik adalah memulai dengan tehnik yang paling superfisial seperti memberi pertanyaan yang berhubungan dengan dampak dari waham tersebut. Dimulai dari sini behavior homework dapat 


\begin{tabular}{c|c|c}
\hline $\begin{array}{c}\text { Jurnal Penelitian Keperawatan } \\
\text { Medik }\end{array}$ & Vol. 2 No. 1 & Edition: May - October 2019 \\
\hline & $\frac{\text { http://ejournal.delihusada.ac.id/index.php/JPKM }}{\text { Revised: 28 October 2019 }}$ & Accepted: 31 October 2019 \\
\hline Received: 16 October 2019 & & \\
\hline
\end{tabular}

digunakan sebagai penjelasan alternatif. Ketakutan dan kemarahan dapat mengurangi intensitas kualitas suatu hubungan. Hindari tantangan disetiap awal dan akhir sesi pertemuan dan diharapkan setiap sesi dapat membantu mengatasi kasus yang timbul (Turkington, et.al., 2006a).

Pertanyaan sokratik dapat berguna sebagai alasan yang mendasar untuk mengatasi keyakinan yang timbul contohnya: keyakinan bahwa saya adalah setan ini berhubungan dengan waham agama (Turkington, et.al., 2006a).

Dengan berprinsip pada kenyataan, ahli terapi berusaha untuk mengembangkan terapi gabungan dengan pasien yang dapat difasilitasi dengan upaya meningkatkan pengertian mengenai simtom yang terjadi (Turkington, et.al., 2006a).

Halusinasi dan waham adalah target untuk melakukan suatu ikatan dan tes realita. ${ }^{7}$ Ketika menerima CBT pasien psikotik merasa ada pihakpihak yang akan mengambil pengalaman mereka dengan menunjukkan ketertarikan atas suatu pengalaman yang menakutkan dan mengancam (Turkington, et.al., 2006a).

CBT biasanya berakhir bila telah tampak adanya pengertian dari pasien, Untuk tetap dapat memperoleh hasil yang maksimal maka diperlukan beberapa sesi pertemuan selanjutnya (Turkington, et.al., 2006a). CBT dapat digunakan secara aman pada pasien skizofrenia, perawat dirumah sakit dapat membantu pasien untuk dapat mengerjakan pekerjaan rumah. Didalam pelaksanaannya CBT dapat digabung dengan terapi keluarga, Assertive Community Treament (ACT), dengan tujuan utama untuk mengurangi terjadinya relaps, meningkatkan coping mechanism yang baik pada pasien skizofrenia melalui peningkatan kepatuhan dan manajemen simtom yang ada (Turkington, et.al., 2006a). Keliru bila menganggap CBT hanya dapat digunakan dalam seting terapi formal, banyak aspek dari CBT yang dapat diimplementasikan setiap hari dalam mengatasi pasien skizofrenia, termasuk didalamnya model ABC (Activating event, Beliefs, Consequences).
Tehnik CBT termasuk didalamnya mengembangkan kepercayaan, normalizing, meningkatkan coping mechanism, tes realita dan bekerja dengan reaksi perilaku terhadap simtom psikotik. Diharapkan dengan CBT dapat memperbaiki fungsi kognitif dan meningkatkan kepatuhan dalam mengkonsumsi obat anti psikotik. CBT juga terlihat potensial untuk mengisi unsurunsur yang hilang didalam merawat pasien skizofrenia (Turkington, et.al., 2006a). Pasien skizofrenia biasanya sangat buruk dalam hal mengembangkan strategi coping sehingga sangat mudah untuk terjadinya halusinasi. Didalam CBT diharapkan strategi coping dapat efektif dalam memperbaiki simtom-simtom (Turkington, et.al., 2006a).

Efek samping dari penggunaan polifarmasi adalah dapat memperburuk kognitif dan timbulnya simtom-simtom psikotik. Perburukan terutama dalam hal atensi, recall dan motivasi sebagai hambatan utama terhadap pengimplementasian terapi psikologis yang efektif. Pemberian antipsikotik konvensional sering kurang membantu terutama dalam hal defisit kognitif dan simtom negatif, strategi yang lebih rasional dengan menggunakan antipsikotik atipikal dosis rendah yang diharapkan lebih efektif dalam terapi simtom negatif (Turkington, et.al., 2006a). Pemberian antipsikotik atipikal dosis rendah yang dikombinasi dengan CBT diharapkan dapat memperbaiki kepatuhan dan perbaikan fungsi kognitif (Turkington, et.al., 2006a).

\section{PROSEDUR CBT PADA PSIKOSIS}

Ada enam prosedur CBT yang dapat dilakukan pasa psikosis, yaitu asesmen, engagement stage, goal setting, normalization, critical collaborative analysis, dan developing alternative explanations.

Assessment dimulai dengan mengikuti hal yang diekspresikan oleh pemikiran pasien mengenai pengalamannya dan disini terapi mulai mendengarkan dengan perhatian. Dapat digunakan skala pengukuran baik yang khusus maupun yang 


\begin{tabular}{c|c|c}
\hline $\begin{array}{c}\text { Jurnal Penelitian Keperawatan } \\
\text { Medik }\end{array}$ & Vol. 2 No. 1 & Edition: May - October 2019 \\
\hline & $\frac{\text { http://ejournal.delihusada.ac.id/index.php/JPKM }}{\text { Revised: 28 October 2019 }}$ & Accepted: 31 October 2019 \\
\hline Received: 16 October 2019 & & \\
\hline
\end{tabular}

umum digunakan untuk memonitor kemajuan yang sedang berlangsung dan bersedia berdiskusi dan berbagi dengan pasien. Bentuk gambar atau diagram dan tulisan dapat sangat berguna. Hasil formulasi dan simtom penyebab dipelihara dan selalu didiskusikan dengan pasien dan informasi yang baru dari ahli terapi juga perlu menjadi pertimbangan.

Pada tahap engagement stage, pertama kali ahli terapi harus dapat menjelaskan tentang terapi yang akan digunakan termasuk didalamnya keamanan penggunaan metode yang akan dipakai untuk mencari penyebab dari penyakitnya. Selanjutnya ahli terapi menggunakan pertanyaan sokratik sebagai penekanan, kemudian mencoba membuat empati dengan pasien caranya berusaha melihat dari sudut pandang dan perasaan tentang penyakit yang dialami oleh pasien dan menunjukkan sifat fleksibel disetiap waktu. Ahli terapi juga harus dapat menekankan bahwa mereka tidak akan menemukan semua jawaban tapi berguna untuk menjelaskan hal-hal yang dapat berkembang. Bentuk terapi yang tidak spesifik disini adalah faktor kejujuran, kehangatan, humor, dan sikap empati adalah merupakan nilai yang sangat berharga dalam tipe terapi ini.

Goal setting (tujuan terapi) yang realistik harus dibicarakan diawal terapi dengan pasien dengan menggunakan motivasi untuk berubah. Menjadi pekerjaan ahli terapi untuk menjamin bahwa tujuan tersebut harus dapat diukur, realistik, dan berhasil. Normalization rationale membantu pasien dalam hal pengalaman decatastropizing psychotic experience. Memberikan pendidikan bahwa pada kenyataannya banyak orang yang tidak memiliki pengalaman dalam serangkaian kejadian seperti stres hebat ketika menghadapi suatu kejadian, menjadi sesak nafas, mengalami penyiksaan, kelaparan, kehausan, tidak bisa tidur dan lain sebagainya, akan tetapi mereka dapat mengurangi kecemasannya. Dengan mendapatkan pengalaman psikotik kemudian menempatkannya menjadi pengalaman yang normal pasien sering merasa sedikit asing. Sebagai konsekuensinya kemungkinan untuk terjadi pemulihan terlihat sangat sedikit.

Untuk melanjutkan proses critical collaborative analysis ini, hubungan terapi harus tetap mengembangkan rasa saling percaya dengan menggunakan pertanyaan sokratik. Beberapa pembuktian harus untuk melawan keyakinan yang maladaptif dapat secara aman dibawa keluar dari pemikiran pasien tanpa harus menimbulkan penyakit lain yang dapat timbul dimana ahli terapi tidak melakukannya dengan cara penghukuman, tetap terbuka dan empati. Disini digali bagaimana keyakinan tersebut dapat terjadi melalui suatu kesimpulan atau merupakan suatu distorsi kognitif. Melihat stress, trauma dan kehilangan dapat menjadi dasar terjadinya perubahan pada psikotik.

Prosedur ini diakhiri dengan developing alternative explanations yang merupakan hal yang paling penting membiarkan pasien berusaha mengembangkan alternatifnya sendiri terhadap asumsi perilaku maladaptif sebelumnya. Lebih baik melihat penjelasan alternatif dan strategi coping yang telah ada pada pemikiran pasien sebelumnya. Sangat berbahaya menempatkan penjelasan yang keras kepada pasien. Pasien memiliki penjelasan sendiri yang mungkin bersifat sementara dan dianggapnya benar, banyak hal yang mempengaruhi pola pikir yang disfungsional. Jika pasien tidak mempunyai penjelasan alternatif maka ahli terapi dapat memberikan ide-ide yang dapat dibangun dalam suatu hubungan (Hansen, et.al., 2006).

Adapun prosesnya adalah assessment dan therapeutic alliance. Assessment merupakan keyakinan yang mendasari harus digali lebih dalam. Pendirian yang teguh dan dipertahankan dan kemungkinan memberikan penjelasan harus selalu ada. Reaksi emosi pada keyakinan tersebut seperti kemarahan, kecemasan, perasaan sedih, harus ditemukan yang sejalan dengan simtom positif seperti tindakan agresif atau simtom negatif seperti avoidance dan withdrawal. Hal yang terpenting mengenai keyakinan tersebut harus 


\begin{tabular}{c|c|c}
\hline $\begin{array}{c}\text { Jurnal Penelitian Keperawatan } \\
\text { Medik }\end{array}$ & Vol. 2 No. 1 & Edition: May - October 2019 \\
\hline & $\frac{\text { http://ejournal.delihusada.ac.id/index.php/JPKM }}{\text { Revised: 28 October 2019 }}$ & Accepted: 31 October 2019 \\
\hline Received: 16 October 2019 & & \\
\hline
\end{tabular}

dipertimbangkan berhubungan dengan masalah self esteem (Turkington, et.al., 1998).

Therapeutic alliance berhubungan dengan adanya waham harus dipelihara jika memungkinkan. Ini kadang dengan adanya waham akan membuat pasien mencoba membuat ahli terapi didalam posisi konfrontasi. Sangat penting untuk menghindari respons konfrontasi, sebaiknya menggunakan penjelasan: baiklah itu adalah suatu penjelasan yang memungkinkan, tetapi adakah penjelasan yang lainnya? atau kita dapat menggunakan kalimat: mari kita gali pembuktian dan kita lihat jika ide anda adalah benar (Turkington, et.al., 1998).

\section{TEKNIK CBT PADA WAHAM}

Teknik yang digunakan CBT pada waham antara lain: peripheral questioning, Inference chaining, dan schema focused work (Turkington, et.al., 1998). Peripheral questioning melibatkan pertanyaan yang berorientasi terhadap kenyataan terhadap keyakinan wahamnya. Contoh: bagaimana sesuatu seperti itu dapat terjadi? terlihat pertanyaan tersebut tidak terlihat mengancam waham dan terlihat normal dengan cara menjaga tanpa adanya ancaman pada self esteem. Pertanyaan ini biasanya sering digunakan pada sesi awal dan secara langsung mengarah kepada realita dan testing homework. Inference chaining, tujuannya disini adalah bekerja dibawah waham, bagian tertentu dari grandiose atau waham sistematik yang biasanya resisten terhadap tehnik yang lain karena mereka benar-benar mengalami fungsi yang terbatas dalam hubungannya dengan self esteem. Sedangkan Schema focused work memfokuskan pada hal adanya ketergantungan dan rendahnya self esteem.

\section{CBT SEBAGAI BAGIAN DARI PENGOBATAN PADA SKIZOFRENIA}

Standar perawatan untuk skizofrenia di Amerika adalah dengan melakukan manajemen kasus yang didukung oleh perawatan di rumah sakit. Kontak perorangan dengan pasien dapat dilakukan oleh perawat psikiatri yang dilakukan sebagai suatu rutinitas biasa misalnya CBT dapat dilaksanakan pada saat menyuntikkan antipsikotik atau pada saat memantau efek samping yang ditimbulkan akibat penggunaan obat anti psikotik pasien diajak berbicara dan sesudahnya diajak melakukan aktivitas.Oleh sebab itu efektifitas perawatan psikologis normalnya tidak dapat selalu tersedia terutama pada pasien skizofrenia yang tidak dapat ditangani (Turkington, et.al., 1998).

Para ahli jiwa umumnya menghabiskan waktu 15 menit untuk setiap pasien rawat jalan dan sebagian besar waktunya digunakan untuk mengamati dan memonitor simtom-simtom yang tampak, dosis pengobatan serta efek samping didapatkan, sehingga pasien menjadi lebih terisolasi dan tidak ada dukungan untuk melakukan kegiatan yang dapat menolong mereka dalam mengatasi simtom psikotik yang muncul. Standar manajemen psikososial yang dilakukan pada pasien dengan skizofrenia di United Kingdom telah dilaporkan berhasil (Turkington, et.al., 1998).

Sebaliknya CBT manual menekankan pada hal yang lebih penting yaitu meningkatkan dan menghabiskan waktu untuk pasien psikotik, membangun kepercayaan dan mulai melakukan suatu tes realita terhadap simtom-simtom mereka. Pada beberapa pasien ini merupakan suatu keuntungan untuk memperbaiki gabungan terapi dan meningkatkan kepatuhan, dengan peningkatan coping maka pengobatan dengan antipsikotik menjadi lebih mudah diterima dan penggunaan zatzat terlarang dapat dikurangi (Turkington, et.al., 1998).

Semenjak CBT digunakan dalam berbagai kondisi telah dikembangkan sejumlah pendekatan untuk memperbaiki fungsi, termasuk didalamnya psikoedukasi, social skill training, kognitif remedial, terapi keluarga, Assertive Community Treament $(\mathrm{ACT})$, interaksi sosial juga memegang peranan didalam CBT (Turkington, et.al., 1998). Seringkali ahli terapi harus berkata dengan jujur: Saya tidak tahu banyak tentang hal ini, Izinkan saya untuk mengkopi beberapa artikel mengenai 


\begin{tabular}{c|c|c}
\hline $\begin{array}{c}\text { Jurnal Penelitian Keperawatan } \\
\text { Medik }\end{array}$ & Vol. 2 No. 1 & Edition: May - October 2019 \\
\hline & $\frac{\text { http://ejournal.delihusada.ac.id/index.php/JPKM }}{\text { Revised: 28 October 2019 }}$ & Accepted: 31 October 2019 \\
\hline Received: 16 October 2019 & & \\
\hline
\end{tabular}

hal ini dan kita akan mendiskusikannya minggu depan (Turkington, et.al., 2008).

Lamanya setiap sesi pertemuan tergantung dari daya tingkat konsentrasi, tahapan terapi, dan tingkat simtom yang ada (Turkington, et.al., 2008), dan tergantung kebutuhan pasien itu sendiri, sehingga terlihat lebih fleksibel (Hansen, 2006). Ada penelitian yang menyebutkan lima hingga enam sesi pertemuan, bahkan hingga rata-rata sepuluh hingga duapuluh sesi pertemuan selama lebih dari sembilan bulan (Guold, et.al., 2004; Hansen, et.al., 2006; Turkington, et.al., 2008). Selain itu juga diperlukan adanya agenda dan jadwal yang dibuat dengan sangat hati-hati dan penuh perhatian. Hindari membuat suatu tindakan yang bersifat mengkonfrontasi atau melakukan suatu tantangan, lebih baik melakukan suatu strategi penarikan diri bila didalam kasus ditemukan suatu kasus eksaserbasi (Turkington, et.al., 2008).

Ahli terapi harus mau bersikap jujur dan terbuka, jelas dan empati serta harus dapat memberika kesempatan untuk berbagi dalam sudut pandang danpendapat mereka. Humor kadangkala dapat digunakan untuk membantu meningkatkan kualitas dari gabungan berbagai terapi dan membuat setiap sesi pertemuan menjadi lebih berkesan. Baik ahli terapi maupun pasien harus dapat mempersiapkan serta mengerjakan pekerjaan rumah pada sesi pertemuan selanjutnya (Turkington, et.al., 2008).

Kunci utama sebagai strategi adalah untuk menormalkan decatastrophized dan destigmatize simtom skizofrenia (Turkington, et.al., 2008). mengembangkan paduan atau gabungan terapi yang didasarkan atas perspektif pasien, memberikan penjelasan alternatif tentang simtom skizofrenia, mengurangi pengaruh simtom positif dan negatif, Menawarkan beberapa alternatif tentang model terapi yang ditujukan untuk kepatuhan pengobatan (Turkington, et.al., 2006b).

Ketika gabungan terapi mulai dibangun dengan adanya suatu kerjasama dan mengembangkan suatu hubungan saling mempercayai kemudian memeriksa simtom psikosis dapat dimulai dengan harapan pasien dapat mengembangkan tilikan mereka terhadap kerentanan pada diri mereka dan tekanan jiwa yang membawa mereka pada simtom psikotik (Turkington, et.al., 2008).

Eksplorasi selanjutnya adalah menggali pengalaman masa kanak yang dapat digunakan dengan menggunakan berbagai formulasi atau rumusan yang telah ada, kemudian didiskusikan dan dan mencari kejelasan (Turkington, et.al., 2008). Implementasi CBT pada skizofrenia maka diharapkan para klinisi harus telah berpengalaman bekerja dengan kualitas tinggi terutama mengenai materi-materi psikoedukasi yang ditujukan untuk meningkatkan kepatuhan (Turkington, et.al., 2006a).

Tim pelayanan kesehatan adalah mereka yang telah dilatih personal therapy (Hogard dan kawan-kawan). Selanjutnya penerapan CBT harus jelas dan terang. Peran psikiatri biologi di United Kingdom telah menegaskan bahwa CBT adalah pelengkap tambahan yang terbaik dan difokuskan pada peningkatan kepatuhan dengan cara meningkatkan coping dan manajemen simtom. Bahwa formulasi CBT dapat digunakan dan digabungkan dengan manajemen psikososial (Turkington, et.al., 2006a). Penggunaan CBT pada skizofrenia tergantung dari kesiapan dan supervisi dimana diperlukan suatu komitmen yang kuat dari pemberi pelayanan kesehatan yang mendukung dan memfasilitasi pelatihan serta supervisi, sebagai realisasinya pasien dapat ditolong dari simtom psikosisnya dan diperlukan pembuktian yang mendukung penerapan CBT (Turkington, et.al., 2006a).

\section{KESIMPULAN}

Munculnya CBT untuk Skizofrenia telah menimbulkan optimistik baru dalam perawatan skizofrenia dalam kondisi stigmatisasi yang cukup tinggi. Dalam jangka waktu panjang perubahan yang diharapkan berkontribusi terhadap perubahan pandangan masyarakat secara umum tentang skizofrenia. 


\begin{tabular}{c|c|c}
\hline $\begin{array}{c}\text { Jurnal Penelitian Keperawatan } \\
\text { Medik }\end{array}$ & Vol. 2 No. 1 & Edition: May - October 2019 \\
\hline & $\frac{\text { http://ejournal.delihusada.ac.id/index.php/JPKM }}{\text { Revised: 28 October 2019 }}$ & Accepted: 31 October 2019 \\
\hline Received: 16 October 2019 & & \\
\hline
\end{tabular}

Walaupun memang pembuktian yang nyata untuk CBT skizofrenia masih memiliki banyak keterbatasan dibandingkan dengan psikoterapi yang lain, paling tidak CBT dapat mengurangi simtom yang buruk, mengurangi angka drop out oleh karena pemakaian obat antipsikotik dan menekan biaya pengobatan.

\section{DAFTAR PUSTAKA}

Jones, C., Cormac, I., Silveira da Mota Neto, J.L., \& Campbell, C. 2008. Cognitive behavioural therapy for schizophrenia (review). The Cochrane collaboration published. John Wiley \& Son's Itd. The Cochrane library.

Gould, R.A., Muesser, K.I., Balton, E., Mays, V., \& Goff, D. 2004. Cognitive therapy for psychosis in schizophrenia: An effect size. Schizophrenia Research, Vol. 48 (2).

Kingdon D G, Turkington D. 2004. Cognitive Therapy of Schizophrenia. Treatment Manuals for Real-world Clinicians. New York: Guilford Publications.

Hansen, L., Kingdon, D., \& Turkington, D. 2006. The ABCs of cognitive behavioral therapy for schizophrenia. Psychiatric time; 23:7.

Stevens, H.H., \& Craske, M.G. 2004. Brief cognitive behavioral therapy: definition and scientific foundations. In: Bond FW, Dryden W, eds. Handbook of brief cognitive behavioral therapy England: John Wiley \& Sons Itd.

Turkington, D., \& Siddle, R. 1998. Cognitive therapy for treatment of delusions. Advances in psychiatric treatment; 4: 235-40.

Turkington, D., Dudley, R., Warman, D.M., \& Beck, A.T. 2006a. Cognitive behavioural therapy for schizophrenia: a review. Focus psychiatry online.org spring; IV: 2: 223-32.

Turkington, D., Martindale, R., Thorsen, G.B. 2008. Schizophrenia. In: Gabbart, G.O., Beck, J.S., Holmes, J., (eds). Oxford textbook of psychotherapy. New York: University Press.
Turkington, D., Kingdon, D., \& Weiden, P.J. 2006b. Reviews and overviews. Cognitive behavior therapy for schizophrenia. Am J psychiatry; 163:365-373.

Rollinson, R., Halg, C., Warner, R., Garety, P., Kuipers, E., Freeman, D., et.al. 2007. The application of cognitive behavioral therapy for psychosis in clinical and research setting. Psychiatric services. Psychiatryonline; 58:10. 